\title{
Midwater trawl catches of adolescent and adult anguilliform fishes during the Sargasso Sea Eel Expedition 1979
}

\author{
A. Post ${ }^{1} \&$ F.-W. Tesch ${ }^{2}$ \\ 1 Ichthyologie, Institut für Seefischerei, Zoologisches Museum Universität Hamburg; \\ Martin-Luther-King-Platz 3, D-2000 Hamburg 13, Federal Republic of Germany \\ ${ }^{2}$ Biologische Anstalt Helgoland (Zentrale); Notkestr. 31, D-2000 Hamburg 52 , \\ Federal Republic of Germany
}

\begin{abstract}
During the research program on the biology and migration of Anguilla spp. carried out with F.R.V. "Anton Dohrn" in 1979, approximately 1300 adolescent and adult anguilliform individuals were caught covering 8 families, 10 genera and 12 species. Observations on each of these species, including horizontal and vertical distributional patterns, are dealt with herein. The appearance of various species in hauls and the absence of adult Anguilla spp. in the catches obtained are discussed.
\end{abstract}

\section{INTRODUCTION}

The research program carried out with F.R.V. "Anton Dohrn" during its 210th (92) cruise (Part II) from 19 March to 9 May 1979 can be subdivided into two periods of different strategy. The main purpose of the first one was the exploration of the migration and biology of Anguilla spp. in the Sargasso Sea. Part of this program was the capture of adult eels by an experimental midwater trawl. The second period was devoted to the Anguilla-problem as well as to a research program on faunal communities in selected depth-zones. This period also included a series of midwater trawl hauls along an Atlantic transect from the Sargasso Sea to the European slope at $48^{\circ} \mathrm{N} 08^{\circ} \mathrm{W}$ via the Azore Islands. R. V. "Friedrich Heincke" which was present in the Sargasso Sea during the same period occasionally made midwater trawl hauls for the same purpose. In this paper we describe anguilliform fish and discuss the reasons for the absence of anguillid adults from our hauls. The results for other deep sea fishes are presented elsewhere.

\section{TRAWLING TECHNIQUES}

Except for a few specimens of migrating silver-eels which have been caught in deep layers of the Shetland-Faroe Channel (Ernst, 1975; Boëtius, pers. communication), no records are known concerning catches of Anguilla spp. during its spawning migration to the Sargasso Sea.

As far as is presently known with the aid of different research techniques, i.e. tracking experiments in the North East Atlantic $(0-500 \mathrm{~m})$ (Tesch, $1978 \mathrm{a}, \mathrm{b})$ or in the 
Sargasso Sea $(0-700 \mathrm{~m})$ (Tesch, 1982); analysis of stomach content of predatory fish in the North East Atlantic (depth $730 \mathrm{~m}$ ) (Reinsch, 1968) and photographs in the Bahama area in a depth of $2000 \mathrm{~m}$ (Robins et al., 1979), migrating eels do not seem to be linked to a special depth-layer but may swim near the surface and in different depths down to $2000 \mathrm{~m}$ or even more.

Using the facilities of F.R.V. "Anton Dohrn", which is built as a stern-trawler, we were able to employ a commercial herring-trawl for our research program. This Engeltrawl (Schärfe, 1969) has a circumference of 1600 meshes and a mouth area of about $700 \mathrm{~m}^{2}$. It can be towed at depths ranging from about $50 \mathrm{~m}$ to a maximum of $2000 \mathrm{~m}$. The stretched mesh size is $200 \mathrm{~mm}$ at the mouth of the gear, and diminishes successively to $40 \mathrm{~mm}$ at its codend. For our program the codend was provided with an inlet of $4 \mathrm{~mm}$ mesh size for the purpose of gathering large and small fishes as well. For midwatertrawling, the engine power used was $1680 \mathrm{kw}$ for a speed of 3 to $4 \mathrm{kn}$.

During the first period (Sargasso Sea) the gear was towed at different depths (stephauls), starting in the deepest layer, followed by steps of 30 to $100 \mathrm{~m}$ for 10 to $20 \mathrm{~min}$ in each layer. Trawling was carried out during daylight as well as after dusk.

During the second period (Transect Sargasso Sea to Bay of Biscay) the gear was towed in one layer only for each haul. According to the methods used on board F.R.V. "Walther Herwig" and F.R.V. "Anton Dohrn" at previous oceanic transects, trawlingtime ranged from $15 \mathrm{~min}$ for shallower layers to one hour for hauls below $1000 \mathrm{~m}$.

Midwater catches in depths shallower than $1000 \mathrm{~m}$ were obtained after dusk only, while hauls deeper than $1000 \mathrm{~m}$ were carried out in daylight, except for one single nighthaul.

As mentioned above, 8 additional trawling stations were carried out by R.V. "Friedrich Heincke". Owing to the much lower engine-power of this vessel a smaller herring-trawl with a circumference of $650200 \mathrm{~mm}$-meshes and a mouth area of about $110 \mathrm{~m}^{2}$ only was used. Following the experiences in the North Sea, a $8.3 \mathrm{~m}$ long codend (mesh size: 20 to $10 \mathrm{~mm}$ ) was used; with a maximum cable length of $750 \mathrm{~m}$ and a speed of 1 to $3 \mathrm{kn}$ a maximum depth of $370 \mathrm{~m}$ could be attained. Actual depths of the trawl were obtained by a pressure sensing transmitter, receiving signals from a hydrophone below the ship (Tesch, 1982). Two hauls were performed during daylight, with the maximum cable length (duration 3 and $6 \mathrm{~h}$ ). Of six night hauls two lasted about one hour (depth 160 and $300 \mathrm{~m}$ ), four were hauls at different depths of 50 to $100 \mathrm{~m}$ depth each and lasting 4 to $6 \mathrm{~h}$.

\section{RESULTS}

The geographical distribution of hauls made by "Anton Dohrn" and "Friedrich Heincke" in the Sargasso Sea are presented in Fig. 1 (Position of ship stations see Tesch, 1982). The transect of "Anton Dohrn" from the Sargasso Sea to the Bay of Biscay is roughly evident from Figs 2 to 4 .

From a total of 66 hauls, 36 of which were carried out in the Sargasso Sea, we did not receive one adult Anguilla individual. As far as "Friedrich Heincke" is concerned, it has become obvious that the gear used is hardly suitable for catching adult or adolescent eels of any kind. Only three small specimens were collected from 8 hauls.

The "Anton Dohrn" collections of adolescent to adult anguilliform specimens in the Sargasso Sea (28 hauls) comprise 733 specimens. Taking the 58 hauls from the transect to 


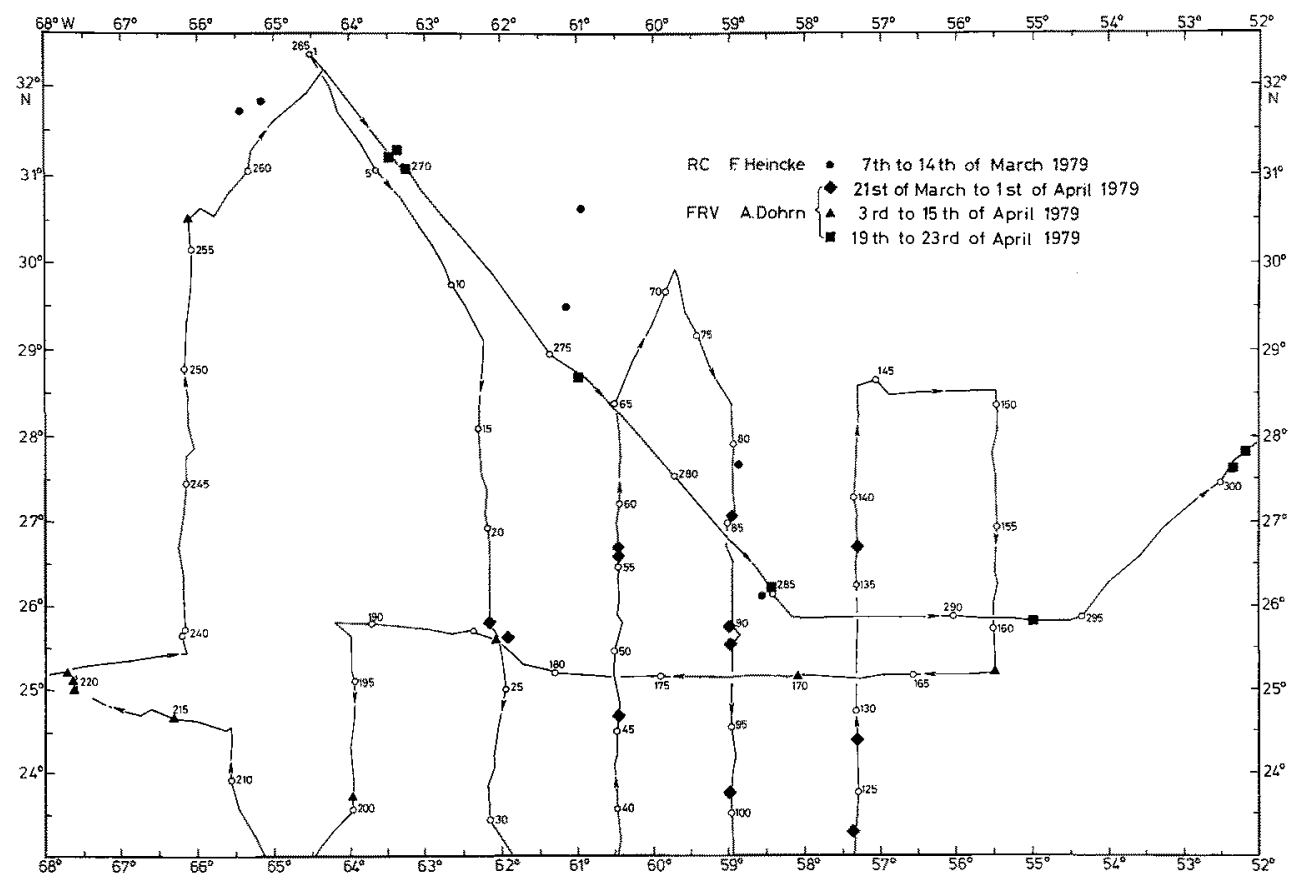

Fig. 1. Positions of pelagic trawl collections of "Anton Dohrn" and "Friedrich Heincke" in the Sargasso Sea. The numbered circles indicate each fifth station during the cruise of "Anton Dohm"

Europe also into account, 1282 specimens were captured covering 8 families, 10 genera and 12 species. As shown by Figs 2-4, no essential differences exist between species occurrence in the Sargasso Sea and in the area from there to the Azores. The most common species (Nemichthys scolopaceus, Serrivomer brevidentatus, Eurypharynx pelecanoides) show no difference of occurrence even far north of the Azores when compared with the occurrence in southern areas.

About $80 \%$ of the total collection was made up by two species only: Serrivomer beani $(57 \%$ ) and Eurypharynx pelecanoides $(23 \%)$; the remaining $20 \%$ cover 10 species.

27 hauls, including 9 step-hauls, were carried out in depths below $1000 \mathrm{~m}$. These hauls brought a markedly higher diversity in species as well as higher numbers of specimens than hauls from shallower layers (Table 1).

Table 1. Number of species collected in different depths

\begin{tabular}{|cccccccccc|}
\hline $\begin{array}{c}\text { Maximum } \\
\text { trawling-depth } \\
(\mathrm{m})\end{array}$ & 0 & 1 & 2 & 3 & 4 & 5 & 6 & 7 & 8 \\
\hline 200 & 4 & 6 & - & 2 & - & - & - & - & - \\
400 & 2 & 7 & - & 1 & 1 & - & - & - & - \\
800 & 1 & 1 & 1 & 1 & 1 & - & - & - & - \\
$>1000$ & - & - & 1 & 4 & 6 & - & - & 3 \\
\hline
\end{tabular}


A. Post \& F.-W. Tesch

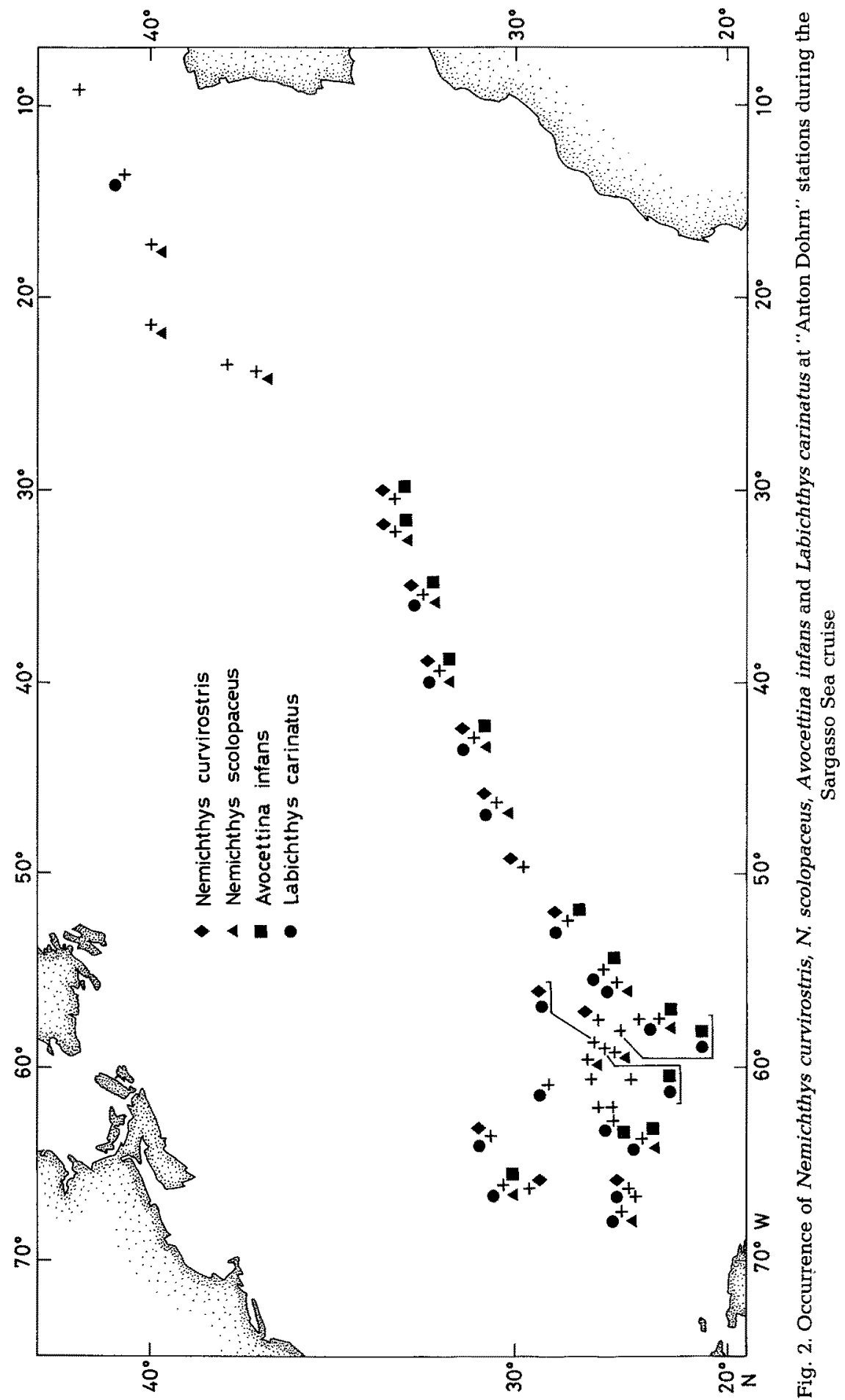


Midwater trawl catches

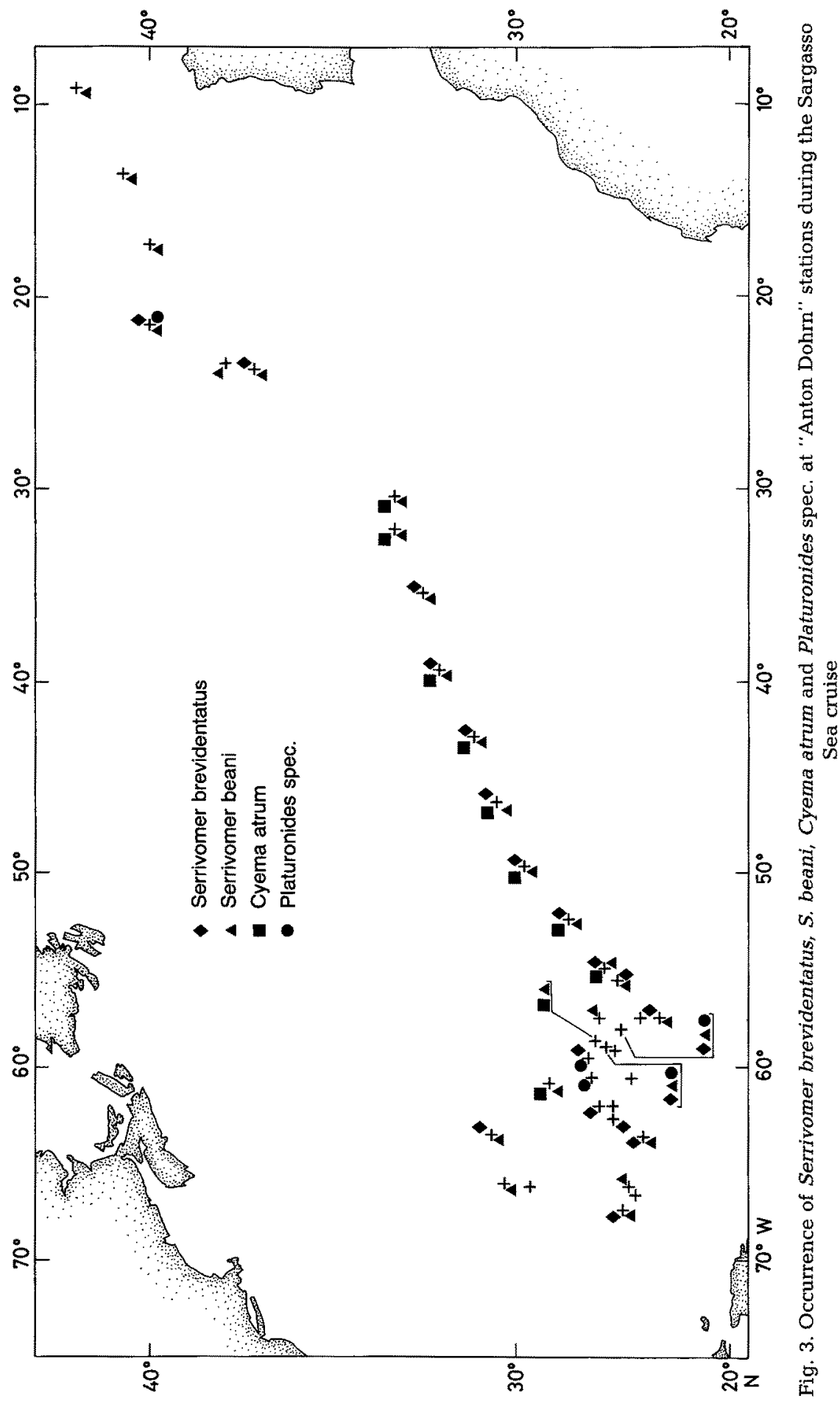


A. Post \& F.-W. Tesch

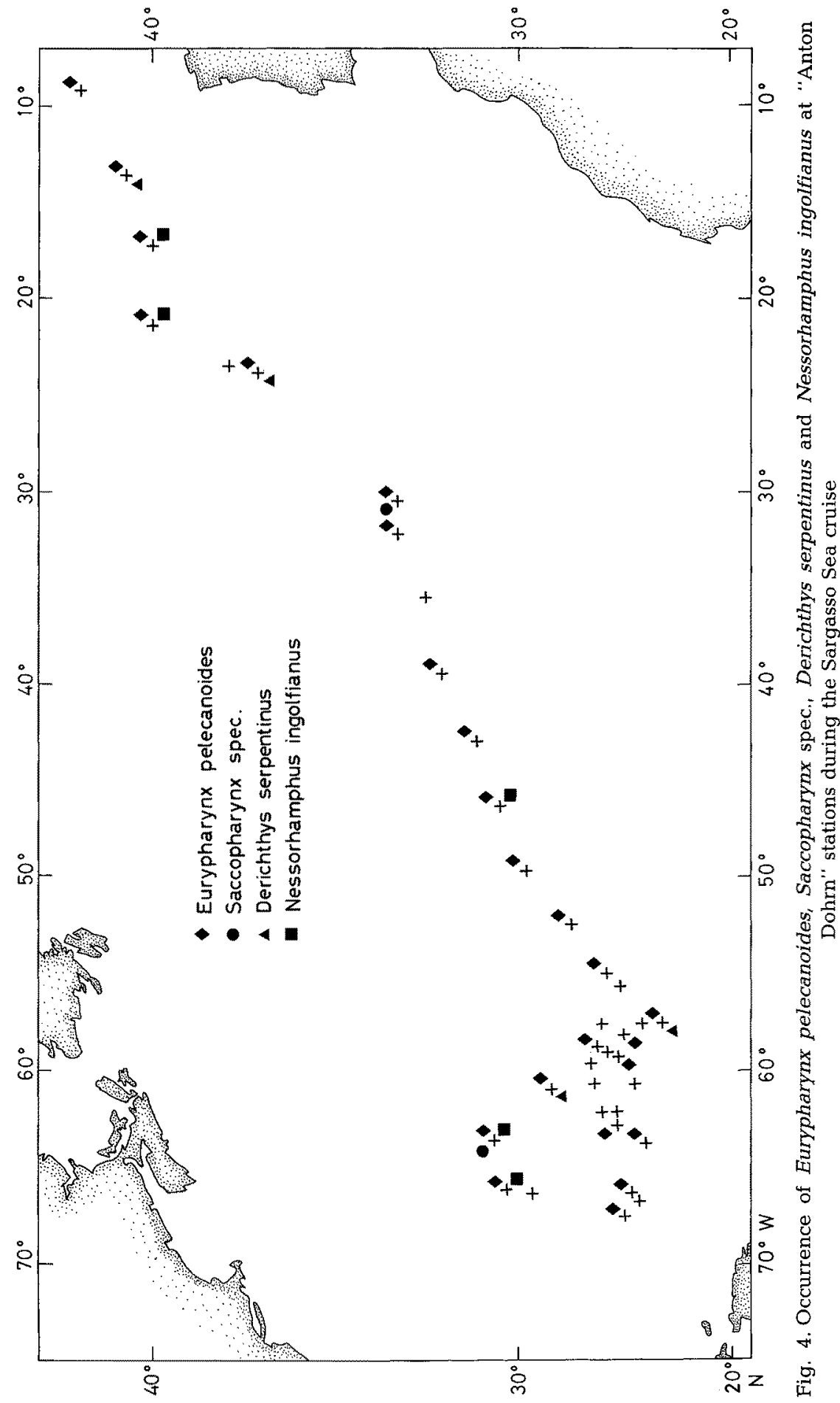


Low numbers of species ( 2 or 3 ) in deep-sea hauls refer to the northern-most stations, which lie outside the distributional area of some species, and to step-hauls, carried out during daylight, towing in deep layers for a few minutes only.

Differences in the number of catches of adult eels according to depths possibly reflect differences in abundance of species. Moreover, it also could be due to the fact, that the net was towed for a period four times longer in deep hauls than in shallower ones. Table 2 shows the amount of specimens, collected during the $2^{\text {nd }}$ period of the expedition ( 37 hauls) for three depth-layers and 12 species.

\section{Survey of species}

\section{Nemichthys scolopaceus}

"Anton Dohrn" station number and number of specimens (in brackets): Stations $5550(1) ; 5588(1) ; 5596(1) ; 5627(1) ; 5666(1) ; 5702$ (1); 5738 (1); 5760 (1); 5819 (1); 5825 (1); 5826 (2); $6827(1) ; 5833$ (1); 5834 (1); 5842 (1); 5850 (2); 5865 (2); 5877 (2); $5884(1)$; $5885(2) ; 5886(1)$.

Nemichthys scolopaceus Richardson, 1848 (Fig. 2) is broadly distributed all over the area covered by the expedition, except for the northern-most stations at $45^{\circ}$ to $48^{\circ} \mathrm{N}$. Thus, a slight gap in geographical distribution between $30^{\circ} \mathrm{N} 50^{\circ} \mathrm{W}$ and the Azore Islands, as reported by Nielsen \& Smith (1978), can be closed now. The absence of samples from our northern-most stations is accidental, as records of this species are known from north of the $50^{\circ}$ latitude.

8 specimens were collected from bathypelagic hauls; 13 from hauls shallower than $400 \mathrm{~m}$, carried out after dusk (Table 1). This is in accordance with our findings from former cruises and indicates a possible nocturnal vertical migration of the species. Usually one, occasionally two specimens were caught per haul. Probably N. scolopaceus lives singly or in very small groups; samples of more than 5 specimens are exceptional and then usually refer to leptocephali and young adolescents.

Among the total of 17 specimens there was one ripe adult male only (Stat. 5623), measuring $512 \mathrm{~mm}$ total length (TL); 7 specimens having 750 to $890 \mathrm{~mm}$ TL were recognized as adult females. The remaining specimens, 160 to $470 \mathrm{~mm}$ long, were juveniles or adolescents.

\section{Nemichthys curvirostris}

Stations 5641 (2 spec.); 5720 (1); 5756 (3); 5772 (2); 5788 (2); 5805 (1); 5813 (1); 5819 (2); 5825 (1); 5826 (1); 5833 (1); 5842 (1); 5849 (2); 5852 (3).

The distribution pattern of Nemichthys curvirostris (Strömman, 1896) (Fig. 2), as represented in our catches, fits into the pattern of records given by Nielsen \& Smith (1978) showing that $N$. curvirostris does not appear north of the $40^{\circ}$ latitude. The species was frequently represented in the Sargasso Sea and along the transect south of the Azore Islands. 15 of the total of 20 specimens, collected at 13 stations, were caught by hauls going deeper than $1000 \mathrm{~m}$. This may indicate a slight difference in vertical distribution betweeen this species and its congener $N$. scolopaceus, or in its behaviour as far as vertical migration is concerned. In accordance with the latter, only one or two, in exceptional cases three, specimens of $N$. curvirostris, were caught per haul. All specimens were adolescent or subadult; not one male was discovered. 


\section{Labichthys carinatus}

Stations 5594 (1); 5602 (2); 5627 (4); 5666 (1); 5674 (1); 5688 (5); 5702 (2); 5720 (1); 5725 (1); 5731 (1); 5738 (6); 5760 (8); 5772 (4); 5780 (2); 5797 (4); 5805 (1); 5817 (1); 5819 (1); 5825 (2); 5833 (1); 5842 (1); 5894 (1).

Labichthys carinatus (Gill \& Ryder, 1883) (Fig. 2) is distributed in all oceans but records are relatively rare. The only one from north of $40^{\circ} \mathrm{N}$ is the type locality $\left(41^{\circ} 13^{\prime} \mathrm{N}\right.$ $\left.66^{\circ} 00^{\prime} 50^{\prime \prime} \mathrm{W}\right)$, a second record is known from north of $30^{\circ} \mathrm{N}\left(32^{\circ} 12^{\prime} \mathrm{N} 64^{\circ} 36^{\prime} \mathrm{W}\right)$; all the rest were collected in the tropical zones between $29^{\circ} \mathrm{N}$ and $21^{\circ} \mathrm{S}$. Our findings augment records for the Sargasso Sea as well as giving new records for Central North Atlantic, north of $30^{\circ} \mathrm{N}$ from $30^{\circ}$ to $50^{\circ} \mathrm{W}$. In 22 hauls we caught a total of 51 specimens, 49 of these in hauls fishing from $1200 \mathrm{~m}$ depth or deeper. The remaining two specimens were juveniles of 200 and $250 \mathrm{~mm}$ TL respectively. The former was caught after dusk at a depth of 306 and the latter by a step-haul, fishing from $800 \mathrm{~m}$ in daylight.

We are in accordance with Nielsen \& Smith (1978) who characterized L. carinatus as a meso- to bathypelagic species, but our results indicate its higher preference for bathypelagic life. Usually one or two specimens were caught per haul but occasionally we collected 4 to 8 specimens, probably owing to a relatively high abundance of this species in our research-area. The majority of the specimens were juveniles, 157 to $590 \mathrm{~mm}$ long. Only a few were longer than $600 \mathrm{~mm}$ and apparently adult, but no studies of sex have been undertaken yet.

\section{Avocettina infans}

Stations 5594 (2); 5602 (3); 5627 (1); 5688 (1); 5702 (1); 5760 (3); 5772 (5); 5797 (3); 5805 (1); 5825 (8); $5833(9) ; 5842$ (4); 5849 (1); 5852 (1).

Avocettina infans (Günther, 1878) (Fig. 2) is broadly distributed in tropical and subtropical regions of all oceans, but is more abundant in the northern hemisphere (Nielsen \& Smith, 1978). Our findings complement the only record known as yet from the Sargasso Sea and from the region between the Sargasso Sea and the Azores. In 14 hauls, all from below $1200 \mathrm{~m}$, we caught a total of 43 specimens. The occurrence in deep layers can only be regarded as accidental but could also be due to the hydrographic conditions in the subtropical region.

From previous hauls carried out in the tropical Atlantic with F.R.V. "Walther Herwig" and F.R.V. "Anton Dohrn", we know this species to live in depths of 160 to 600 $\mathrm{m}$ as well, at least after dusk. If $A$. infans were adapted to a relatively narrow range of water temperature, it would live in much shallower depths in tropical zones than it does in subtropical ones. The species seems to be relatively abundant. Samples of 3 to 9 specimens were as frequent as samples of one or two only. Most specimens were juveniles; only 10 specimens, with lenghts varying between 500 and $600 \mathrm{~mm}$, seem to be subadults or adults, but no special studies on sex and age have been undertaken yet.

\section{Serrivomer beani}

Stations 5594 (44); 5602 (31); 5627 (41); 5641 (2); 5666 (9); 5674 (27); 5688 (39); 5702 (15); $5720(17) ; 5725$ (16); 5738 (23); 5738 (47); 5760 (52); 5772 (23); 5780 (6); 5788 (6); 5797 (16); 5805 (14); 5812 (23) 5817 (12); 5825 (20); 5827 (1); 5833 (39); 5842 (42) 5843 (55); 5852 (37); 5865 (36); 5869 (2), 5875 (18); 5884 (8); 5893 (5); 5911 (7). 
Serrivomer beani (Gill \& Ryder, 1884) (Fig. 3) is broadly distributed in the Atlantic Ocean from $65^{\circ} \mathrm{N}$ through the subtropics and tropics to the southern subtropical convergence at about $42^{\circ} \mathrm{S}$. $S$. beani is one of the most abundant mesopelagic eel species, if not the most abundant, in the Atlantic.

We always caught it when fishing deeper than $1000 \mathrm{~m}$ in the Sargasso Sea and along the transect, receiving on an average 25 specimens per haul. 11 specimens were collected from stephauls beginning at 600 and $800 \mathrm{~m}$ respectively. Six further samples of one or two specimens were collected from shallower hauls in less than $300 \mathrm{~m}$. But these may not be real samples. At all doubtful stations, the haul was carried out immediately after the net had fished $1200 \mathrm{~m}$ deep or more. So we suspect that at least some of the fish from the greater depth remained in the net and consequently should be referred to the deeper haul. In 32 hauls - excluding the 6 mentioned above - we caught a total of 731 specimens, 710 coming from hauls deeper than $1000 \mathrm{~m}$. The preference for bathypelagic life in $S$. beani could be due to the same hydrographical conditions as described for $A$. infans, as numerous specimens of $S$. beani were caught by F.R.V. "Walther Herwig" and "Anton Dohrn" in the tropical Atlantic in layers shallower than $600 \mathrm{~m}$. Our smallest specimen measured $90 \mathrm{~mm}$, the longest one $780 \mathrm{~mm}$ in TL. Studies on sex and age have not been undertaken yet but ripe females have been caught from at least one of the westernmost stations.

\section{Serrivomer brevidentatus}

Stations 5594 (2); 5602 (1); 5627 (7); 5666 (1); 5674 (2); 5688 (3); 5702 (2); 5738 (3); $5760(1) ; 5772(3) ; 5774(2) ; 5797(4) ; 5805(1)$; $5812(4) ; 5817 ; 5818(3) ; 5825(6) ; 5827(4)$; 5833 (5); 5842 (5); 5865 (2).

Serrivomer brevidentatus (Roule \& Bertin, 1929) (Fig. 3) is widely distributed in the Sargasso Sea and along our transect up to $41^{\circ} \mathrm{N}$, but is less frequent than its congener $S$. beani. The highest number of specimens caught was 7 , received at station 5627 by a step-haul beginning at a depth of $1800 \mathrm{~m}$. During previous cruises in the Atlantic with F.R.V. "Walther Herwig" and F.R.V. "Anton Dohrn" we caught S. brevidentatus from about $55^{\circ} \mathrm{N}$ through the subtropics and tropics to about $37^{\circ} \mathrm{S}$. No records are known from other oceans so far.

In 20 hauls of the Sargasso Sea Expedition we caught a total of 58 specimens, 51 of which were collected by 18 hauls fishing deeper than $1000 \mathrm{~m}$. Six juveniles $(110$ to $265 \mathrm{~mm}$ TL) were caught after dusk in $250 \mathrm{~m}$ and $380 \mathrm{~m}$ depth respectively. Both hauls were not preceeded by deeper ones. The remaining specimens were received from a step-haul after dusk, beginning at $800 \mathrm{~m}$ depth. Except for four specimens which were longer than $550 \mathrm{~mm} \mathrm{TL}$, all specimens seem to be juveniles, but no studies on sex and age have been carried out yet.

\section{Platuronides sp.}

Stations 5560 (3); 5588 (1); 5594 (1); 5602 (1); 5875 (1).

From 5 hauls in the Sargasso Sea we received 9 specimens of Platuronides sp.; an additional one was caught at station $5875\left(45^{\circ} \mathrm{N}\right)$, when the net was towed at a depth of $2000 \mathrm{~m} .5$ of the specimens from the Sargasso Sea were caught by net fishing below $1000 \mathrm{~m}$, the remaining four by step-hauls, beginning at $600 \mathrm{~m}$, after dusk. The specimens range in length from 111 to $470 \mathrm{~mm}$ TL. 
The taxonomical status of Platuronides sp. and its respective relationship to Serrivomer spp. is uncertain and has come under discussion recently. The Serrivomeridae as a whole need to be revised.

\section{Cyema atrum}

Stations 5780 (4); 5788 (8); 5797 (2); 5805 (3); 5812 (1); 5817 (2); 5825 (6); 5827 (1); $5833(6) ; 5849(1) ; 5850(1) ; 5852$ (1).

Cyema atrum (Günther, 1878) (Fig. 3) is broadly distributed in all oceans but was regarded as relatively rare. The distributional pattern as given by Grey (1956) includes the tropical and southern Pacific from Lower California to north-east of New Zealand, the Indian Ocean from Maledives Islands to $50^{\circ} \mathrm{S}$ and the Atlantic Ocean from $39^{\circ} \mathrm{N}$ to $30^{\circ} \mathrm{S}$. Our findings fit into this pattern so far, as we caught $C$. atrum from the Sargasso Sea along the transect to $36^{\circ} \mathrm{N}$. But this does not indicate the northernmost distribution of this species: C. atrum was caught by F.R.V. "Walther Herwig" during the OverflowExpedition in 1973 between about $55^{\circ} \mathrm{N}$ and $62^{\circ} \mathrm{N}$. Further records of this species from the "Walther Herwig" and "Anton Dohrn" cruises to South America refer to the northern tropical Atlantic and to the South Atlantic from $5^{\circ} \mathrm{S}$ to about $51^{\circ} \mathrm{S}$.

Grey calls $C$. atrum a bathypelagic species. We are in accordance with her as 34 out of 36 specimens were collected from hauls fishing deeper than $1200 \mathrm{~m}$. But two records of adult specimens collected from $380 \mathrm{~m}$ and $350 \mathrm{~m}$ depth respectively (Stations 5827 and 5850) indicate occasional presence of this species in mesopelagic layers. C. atrum cannot be regarded explicitely as a rare species. It seems to live singly or in small groups. Usually we caught one or two specimens only but there are samples of three to 8 and - at a previous cruise of "Walther Herwig" - of up to a maximum of 17 specimens per haul. The smallest specimen taken during the present cruise was $95 \mathrm{~mm}$, the largest one $122 \mathrm{~mm}$ standard length (SL). This is within the range of subadults and adults.

\section{Derichthys serpentinus}

Stations 5588 (1); 5627 (2); 5780 (1); 5865 (1); 5894 (1).

A total of six specimens of Derichthys serpentinus (Gill, 1884) (Fig. 4) were collected at three stations in the Sargasso Sea and at two additional stations north of the Azores Islands.

D. serpentinus is broadly distributed in the Atlantic and has been caught by F.R.V. "Walther Herwig" and F.R.V. "Anton Dohrn" from about $58^{\circ} \mathrm{N}$ through the central Atlantic to about $40^{\circ} \mathrm{S}$ by meso- to bathypelagic trawling, the shallowest positive haul at $200 \mathrm{~m}$, the deepest one at $2000 \mathrm{~m}$. It seems to live singly, as usually only one specimen is caught per haul. Two, three or four specimens per haul are exceptional. Our present records refer to juveniles and adults measuring from 176 to $349 \mathrm{~mm} \mathrm{TL}$; one specimen was in spawning condition (Stat. 5725).

\section{Nessorhamphus ingolfianus}

Stations 5760 (1); 5772 (1); 5875 (1); 5884 (1); 5818 (1).

Nessorhamphus ingolfianus (Schmidt, 1912) (Fig. 4) an oceanic form is known from all oceans, ranging in depth from the surface to bathypelagic realms. In the Atlantic it has been collected by F.R.V. "Walther Herwig" and "Anton Dohrn" from about 60 "N through the tropics to about $40^{\circ} \mathrm{S}$.

On the present cruise we received a total of 5 specimens, 3 collected in the Sargasso 
Sea and 2 during the transect, north of the Azores Islands. Four of these specimens were taken in hauls deeper than $1000 \mathrm{~m}$, the fifth one was caught in a depth between 155 and $195 \mathrm{~m}$ only and after dusk. A single adult of $656 \mathrm{~mm}$ TL was caught by a step-haul starting in $1800 \mathrm{~m}$ depth. The others were juveniles of $252 \mathrm{~mm}$ TL. According to our experiences, $N$. ingolfianus is rarely caught in midwater trawls, since on the occasion of our previous cruises this species was either missing completely, or was represented by only 1 or very exceptionally by 2 or 3 specimens.

\section{Eurypharynx pelecanoides}

Stations 5594 (6); 5602 (10); 5627 (13); 5688 (6); 5702 (10); 5720 (12); 5725 (15); 5738 II (8); 5738 IV (11); 5760 (32); 5772 (8); 5780 (16); 5788 (7); 5797 (9); 5805 (9); $5812(11)$; 5817 (4); 5825 (19); 5833 (12); 5835 (1); 5849 (13); 5852 (16); 5865 (16); 5875 (4); 5884 (12); $5893(7) ; 5911(1)$.

Eurypharynx pelecanoides (Vaillant, 1882) (Fig. 4) is distributed in all oceans but records are more frequent from the Atlantic, where it has been caught by F.R.V. "Walther Herwig" and "Anton Dohrn" from about $65^{\circ} \mathrm{N}$ through the tropics to about $41{ }^{\circ} \mathrm{S}$. Except for two hauls, it was always present in our hauls throughout our cruise whenever the net fished deeper than $1200 \mathrm{~m}$. From 26 bathypelagic hauls we collected 287 specimens. One additional adolescent of $230 \mathrm{~mm}$ TL was caught at $345 \mathrm{~m}$ depth after dusk, thus representing the shallowest record so far.

$E$. pelecanoides is one of the most abundant bathypelagic eels. It seems to swim in small groups, as we caught from 4 to 32 specimens (an average of 7 to 12 specimens) per haul. The specimens' lengths range from 95 to $750 \mathrm{~mm}$ TL. Special studies on sex and age have not been undertaken yet.

\section{Saccopharynx sp.}

Stations 5772 (1); 5852 (1).

Two unidentified specimens of Saccopharynx (Fig. 4) were collected from south of Bermuda Islands and south of Azores Islands respectively, caught by nets fishing below $1600 \mathrm{~m}$ depth. Both specimens were adults, measuring 980 and $1080 \mathrm{~mm}$ TL respectively.

Table 2. Number of specimens collected of each species in different depths

\begin{tabular}{|c|c|c|c|c|c|c|c|c|c|c|c|c|c|}
\hline $\begin{array}{l}\text { Depth } \\
\text { (m) }\end{array}$ & $\begin{array}{l}\text { Minu- } \\
\text { tes of } \\
\text { towing }\end{array}$ & 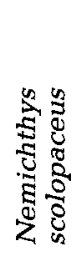 & 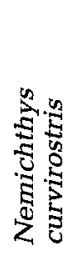 & 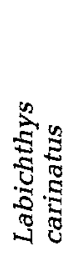 & 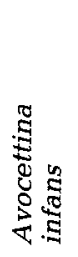 & 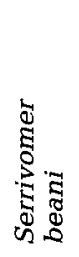 & 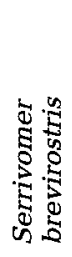 & 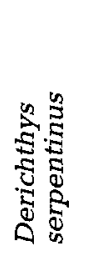 & 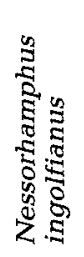 & 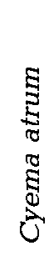 & 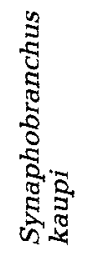 & 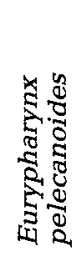 & 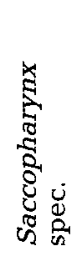 \\
\hline \multirow{4}{*}{$\begin{array}{l}\text { to } 200 \mathrm{~m} \\
\text { to } 400 \mathrm{~m} \\
>1000 \mathrm{~m} \\
\text { total number } \\
\text { of specimens }\end{array}$} & 15 & 3 & 2 & 0 & 0 & 26 & 1 & 0 & 1 & 0 & 0 & 0 & 0 \\
\hline & 15 & 7 & 3 & 1 & 0 & 4 & 5 & 1 & 0 & 2 & 0 & 1 & 0 \\
\hline & 60 & 7 & 15 & 31 & 36 & 405 & 33 & 2 & 4 & 34 & 1 & 206 & 2 \\
\hline & - & 17 & 20 & 32 & 36 & 435 & 39 & 3 & 5 & 36 & 1 & 207 & 2 \\
\hline
\end{tabular}




\begin{tabular}{|c|c|}
\hline 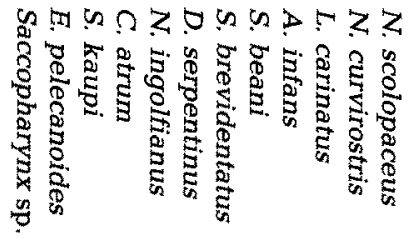 & 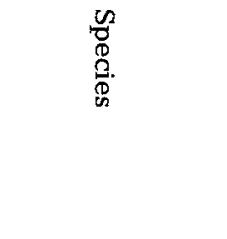 \\
\hline 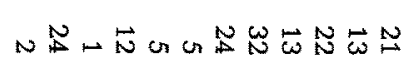 & $\begin{array}{l}\text { Number of } \\
\text { positive hauls }\end{array}$ \\
\hline 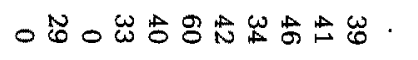 & N. scolopaceus \\
\hline 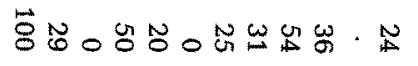 & N. curvirostris \\
\hline 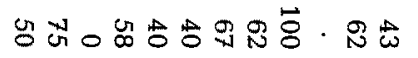 & L. carinatus \\
\hline 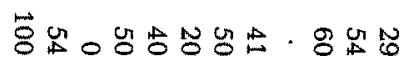 & A. infans \\
\hline 뵹 & S. beani \\
\hline 녕 & S. brevidentatus \\
\hline $0 \infty 0 \infty 0 \cdot \infty 0 \infty 00 \vec{A}$ & D. serpentinus \\
\hline V̆丶 & $N$. ingolfianus \\
\hline 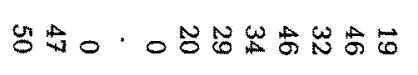 & C. atrum \\
\hline $0 \$ .0000 \omega 0000$ & S. kaupi \\
\hline g. & E. pelecanoides \\
\hline$\triangle 0 \infty$ ơ & $\begin{array}{l}\text { Saccopharynx } \\
\text { sp. }\end{array}$ \\
\hline $0000 \tilde{O} 000000 \tilde{W}$ & None \\
\hline 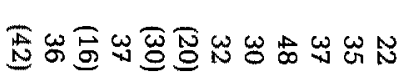 & $\begin{array}{l}\text { Average of } \\
\text { percentage }\end{array}$ \\
\hline
\end{tabular}




\section{Synaphobranchus kaupi}

Station 5893.

A single juvenile specimen of Synaphobranchus kaupi (Johnson, 1862) was caught at the northernmost station of the transect. This species lives in the benthic zone on the continental slope. It was pure chance that this species was caught in a midwater trawl.

\section{Survey of anguilliform communities}

Analysis of species communities in different depths at different seasons and during different hours of the day demands intensive research, far more intensive than was in our power to carry out during our cruise. Consequently, the information provided by our results is meagre and should be used with precaution. Nevertheless, we shall show the rate of association observed during our cruise in respect to the anguilliform species (Table 3).

Table 3 provides information about the relative frequency at which each species, named in the left vertical column, occurred in our hauls (numbers in first vertical column after species' name). This relative frequency of positive hauls is compared to the relative frequency (\%) at which other species, named in the horizontal column, were present in these positive hauls (numbers at conjunction of vertical and horizontal column). For example: 13 of our hauls contained $N$. curvirostris $s_{i}$ in $85 \%$ of these positive $N$. curvirostris hauls, $S$. beani was also present. However, $N$. curvirostris was present in only $31 \%$ of the positive $S$. beani hauls. This table must thus be read horizontally.

The percentages presented in Table 3 offer no special information of their own accord; however, comparison of the multiple correlation of the species studied points out interesting implications. For example, $A$. infans and $C$. atrum, both of which were caught at a similar frequency, are present together with $S$. beani as well as with $E$. pelecanoides to a very high degree; i.e. in 80 to $100 \%$ of the hauls in which $A$. infans and C. atrum occurred, S. beani and E. pelecanoides were present. $A$. infans and C. atrum, however, were quite distinctly not caught together so frequently. It is quite possible that these two species have a slightly overlapping distribution whereas $E$. pelecanoides is able to live in a biotope encompassing the two.

The last vertical column of Table 3 presents the averages taken of the percentages. Each number, having no meaning in its own right, offers us however, when the species are compared, an indication of the "associational trend" of each species - always based, of course, on our data. For example, we find that $A$. infans occurs to a much higher extent together with other species than does $N$. curvirostris or $S$. brevidentatus, even though the two latter species were caught just as frequently and just as numerously as the former.

\section{DISCUSSION}

Attempts to capture adult Anguilla spp. were unsuccessful. This could have had several reasons:

(1) The midwater trawl used to catch herring is not suitable for the capture of eels. The meshsize, from the front part to nearly the beginning of the codend, is too big. The eel fisheries in the North Sea use bottom trawls with smaller meshsizes. However, the alternative use of modified Krill-net, with a smaller mesh-size, was renounced because 
of its having too small a mouth. On the other hand, it has been proven on previous cruises that the MT 1600 is able to catch quick-swimming fishes and in addition adult eels of different families. For instance, large adults of Saccopharynx sp. and of Nessorhamphus ingolfianus, and even the smaller Derichthys serpentinus and Cyema atrum were caught during our cruise, indicating the capability of the gear to catch eels. Keeping in mind that mature Anguilla sp. are usually of a low vitality and a delicate condition, as known from hormonal experiments (e.g. Tood, 1979), we should have caught some if there had been any.

(2) Anguilla spp. may travel at greater depth than suspected and perhaps close to the bottom. The maximum fishing depth was $2000 \mathrm{~m}$. Another 2000 or $3000 \mathrm{~m}$ below this level were left untouched by our trawling-techniques. So, if Anguilla specimens migrate or inhabit layers deeper than $2000 \mathrm{~m}$ we could never have picked them up from there. Some facts indicate that Anguilla specimens sink into great depths or are even bottom dwelling fishes (Robins et al., 1979). But there are some contraindications too which seem to force Anguilla spp. into much shallower layers, at least for a while. Experiments on artificial ripening of eels only took place when temperatures were not lower than $18^{\circ} \mathrm{C}$ (see review: Tesch, 1977). Larvae occurrence, including specimens a few days old, was found to be not deeper than $160 \mathrm{~m}$ (Schoth \& Tesch, 1982).

(3) Anguilla may be too scattered on their way to or in the Sargasso Sea or they may also be clumped in groups. Trying to detect a limited number of eels during a limited time space and in a large area is like trying to find a needle in a haystack and success finally depends on the amount of effort. Fishing for about 16 hours in 100 to $400 \mathrm{~m}$, 6 hours in 400 to 1000 , and 25 hours in 1000 to $2000 \mathrm{~m}$ as we did, may indeed still be far too small an effort to catch Anguilla specimens.

But obviously it is not too small an effort when trying to catch other eels from other families. But all these eels are not just visitors to the Sargasso Sea. They all spend their lives or long parts of their lives in this area. They are adapted to feed there, not only to spawn there. They undertake diurnal vertical migration, following their prey into various depth layers such as those within reach of our nets and even rush actively into the fishing net while hunting. After having started its migration to the Sargasso Sea, Anguilla does not feed; consequently, it does not follow migrating prey.

On studying the abundance of leptocephali, Anguilla turns out to be the most abundant eel of all, closely followed by Serrivomer spp. (Tesch et al., 1979). While Serrivomer spp. is the most common metamorphosed eel in our catches, Anguilla spp. is totally lacking. In fact the occurrence of leptocephali of these two genera may not be correlated to the occurrence of any other developmental stages of the genera in question. Stages to be correlated are leptocephali to leptocephali and ripe adults to ripe adults respectively, as no adolescents of Anguilla spp. exist in the area. From this point of view, the abundance of Serrivomer - and of any other eel-species - decreases remarkably. Only very few of our collected anguilliform specimens are really adult. The majority belongs to ontogenetic stages which are not represented by Anguilla spp. in this area.

But back to Serrivomer spp., the obviously most abundant eel genus of the Sargasso Sea: adults inhabiting this area are presumably born here, or not far away. The fluctuation of individuals is stable and well-balanced. Not so with Anguilla spp. which have a long way to migrate and the success of this migration depends on their overcoming difficulties. Loss of individuals cannot be compensated so easily. Evolu- 
tional compensation of high loss in individuals usually results in increasing reproductional rates. Serrivomer spp. have much smaller ovaries than Anguilla spp. but their eggs are about ten times larger in volume than the eggs of the latter (Stibane, 1981). Nevertheless, a higher number of Anguilla leptocephali can be collected in the Sargasso Sea than Serrivomer leptocephali. Consequently the number of spawning females in Serrivomer must be considerably higher than in Anguilla to compensate the low number in offspring. Vice versa the high number of eggs in an Anguilla ovary allows a reduction in the rate of spawning females in this species. This underlines once more how small the chance is of meeting adult Anguilla specimens in the Sargasso Sea.

Calculations, based on stock estimates of the European eel (Tesch, 1980 a) $\left(30-10^{6}\right.$ females) and a spawning area of $2-10^{6} \mathrm{~km}^{2}$, prove that 500 hauls of "Anton Dohrn" are necessary to catch one female eel, provided its occurrence is not deeper than $2000 \mathrm{~m}$ and half of the stock is present during the peak of the spawning time. Another estimate presented by Harding (Tesch, 1980 b) suggests that 10000 hauls are required to capture one adult female with the present techniques.

The likelihood of successful trawling on adult Anguilla spp. - without the necessary information of its whereabouts - is therefore very small. Other techniques should therefore be developed. We propose an improvement of the tracking method as used during this expedition (Tesch, 1982) or the use of hormonally maturated eels as lures or the direct use of a possible eel pheromone, hydro-acoustic techniques, television and the use of light as an attractant.

With respect to other anguilliform fish, all the hauls of R.V. "Friedrich Heincke" except one exhibited negative results. An easy explanation is the sixfold smaller mouth area of its midwater trawl compared with that of F.R.V. "Anton Dohrn". In addition, the towing depth was so shallow that the mesopelagic eels could only seldom be caught.

Acknowledgements. The authors wish to thank Dr. C. Karrer (Hamburg), Dr. J. G. Nielsen (Copenhagen) and Dr. D. G. Smith (Galveston, Texas) for the determination of anguilliform fishes on board and $C$. Berger for assistance in preparing the English text.

\section{LITERATURE CITED}

Boëtius, I. \& Boëtius, J., 1981. Fecundity of the European eel. - Dana (in press).

Ernst, P., 1975. Catch of an eel (A. anguilla) northeast of the Faroe Islands. - Annls biol., Copenh. 32, 175.

Grey, M., 1956. The distribution of fishes found below a depth of $2000 \mathrm{~m}$. - Fieldiana, Zool. 36 , 75-337.

Nielsen, J. G. \& Smith, D. G., 1978. The eel family Nemichthyidae (Pisces, Anguilliformes). - Dana Rep. 88, 1-71.

Reinsch, H. H., 1956. Fund von Flußaalen im Nordatlantik. - Arch. FischWiss, 19, 62-63.

Robins, C. R., Cohen, D. M. \& Robins, C. H., 1979. The eels, Anguilla and Histobranchus, photographed on the floor of the deep Atlantic in the Bahamas. - Bull. mar. Sci. 29, $401-405$.

Schärfe, $J$, 1969. The German one-boat midwater trawl (development since 1959 to the beginning of 1968). - Protok. FischTech. 12 (50), 1-75.

Schoth, M. \& Tesch, F.-W., 1982. Spatial distribution of 0-group eel larvae (Anguilla sp.) in the Sargasso Sea. - Helgoländer Meeresunters. 35, 309-320.

Stibane, F., 1981. Die Verteilung pelagischer Fischeier aus Fängen der deutschen SargassoseeExpedition 1979. - Dipl.-Arb., Univ. Hamburg, 127 pp. (unpubl.). 
Tesch, F.-W., 1978 a. Horizontal and vertical swimming of eels during the spawning migration at the edge of the continental shelf. In: Animal migration navigation and homing. Ed by $\mathrm{K}$. Schmidt-Koenig \& W. T. Keaton. Springer, Berlin, 378-391.

Tesch, F.-W., $1978 \mathrm{~b}$. Telemetric observations on the spawning migration of the eel (Anguilla anguilla) west of the European continental shelf. - Envir. Biol. Fish. 3, 203-209.

Tesch, F.-W., 1977. The eel. Chapman \& Hall, London, 434 pp.

Tesch, F.-W., 1980a. Occurrence of eel Anguilla anguilla larvae west of the European continental shelf, 1971-1977. - Envir. Biol. Fish. 5, 185-190.

Tesch, F.-W., 1980b. Report on the available data of the Atlantic Anguilla larvae, presented to the ICES planning group for the Atlantic eel expedition. - C.M./ICES, M7, 1-9.

Tesch, F.-W., 1982. The Sargasso Sea Eel Expedition 1979. - Helgoländer Meeresunters. 35, 263-277.

Tesch, F.-W., Kracht, R., Schoth, M., Smith, D. G. \& Wegner, G., 1979. Report on the eel expedition of F.R.V. "Anton Dohrn" and R.K. "Friedrich Heincke" to the Sargasso Sea 1979. - C.M./ICES, M6, 1-29.

Todd, P. R., 1979. The hormon-induced maturation of New Zealand freshwater eels. - Rapp. P.-v. Réun. Cons. int. Explor. Mer 174, 91-97. 